\title{
Policy Adoption of Forest Management Unit: A Knowledge Diffusion Analysis
}

\author{
Julijanti $^{{ }^{1 *}}$, Bramasto Nugroho ${ }^{2}$, Hariadi Kartodihardjo ${ }^{2}$, Dodik Ridho Nurrochmat ${ }^{2}$ \\ ${ }^{1}$ Graduate School of Bogor Agricultural University, Dramaga Main Road, Campus IPB Dramaga, Bogor, Indonesia 16680 \\ ${ }^{2}$ Department of Forest Management, Faculty of Forestry, Bogor Agricultural University, Academic Ring Road, Campus IPB \\ Dramaga, PO Box 168, Bogor, Indonesia 16680
}

Received, May 9 2014/Accepted August 11, 2014

\begin{abstract}
Within the policy adoption process of Forest Management Unit (FMU) concept, there has been disagreement of stakeholders on FMUs concept. This disagreement is caused by the exchange of knowledge, information, and perception among stakeholders involved. The results of these interactions could speed up, slow down, and prevent the adoption process of FMU policy. The study objective was analyzing process of knowledge diffusion of FMUs development policy and stakeholders interaction in PFMU Batutegi and PFMU Kotaagung Utara, Indonesia. Adoption process was analyzed by the logical diffusion technique based on knowledge time of FMUs concept received and its interaction space. Social interaction among stakeholders was analyzed using method developed by International Development Studies analysis, i.e. interaction among discourse/narrative, actors/networks and politics/interests. The results showed that knowledge diffusion of FMUs concept in both PFMU tends to cascade diffusion. Factors was affecting of it process were network, role of opinion leaders, willingness to know, and understand on FMUs concept. Indicative strategy is needed as anticipating and overcoming an obstacle in its internalization process, i.e. harmonization of legislative and executive relationship, building an opinion the importance of FMU, and optimalizing network for bureaucratic problems.
\end{abstract}

Keywords: Forest Management Unit, knowledge diffusion, network, policy adoption

*Correspondence author; email:julijanti@gmail.com,tel.:+62-81380545251

\section{Introduction}

Law Number 5/1967 on Forestry is a government rule in Indonesian forest management system. Understanding to this Act has implications to forest concessions rights (FCR) and exclusion of forest management activities. It is resulting in forests damage, environmental, and social issues. Kartodihardjo (2010) stated that deforestation was caused by human action as a result of mindset used. Ismanto (2010) states that from 301 companies which have natural forest management license in Indonesia, only $15 \%$ show good performance, $45 \%$ show moderate performance, and the rest $(40 \%)$ show poor performance (Kartodihardjo 2010). $\mathrm{He}$ also said that there $40 \%$ concession area were damaged due to bad business performance.

Forest is one of the natural resources that have characteristics of common pool resources (CPRs), so in its management should be consider the stakeholders involvement. These characteristics, among others, which embedded to the state forest. State forest is a forest area that the management is entrusted to the Government, namely the Ministry of Forestry. Property right of state forest is the state, so the state should making and stipulating of rules in its management. The power of arrange if it is not followed by the principle of fairness or clarity in the property rights, utility rights and management rights by stakeholders, then it can cause a conflict which has implications to forest sustainability. Therefore, forest management institutions on site level is very importance as implementers of government policies.

Protection Forest Management Unit (PFMU) Batutegi is a provincial FMU that consists of 4 regencies, i.e. Tanggamus, Pringsewu, Central Lampung, and West Lampung. PFMU Kotaagung Utara is a regency FMU with jurisdiction in Tanggamus regency. Forest cover in both PFMU is about $8 \%$, while approximately $92 \%$ area has already been converted to farmland, settlements, and shrub. Community has been managing most of forest area. Diamond (2005) stated that failure and successful of natural resource management because lack of understanding on complex social conditions by decision-makers (Kartodihardjo 2006a).

In addition to the uncertainty issues of forest area status, lack of forest management on site level was problems root of forest destruction (Kartodihardjo 2010). The important meaning of the FMU roles that every inch of forest land, there are managing namely FMU. Based on mandates of Law Number 41/1999 and Government Regulation Number 6/2007, FMUs development policies are 'a must.' FMU is an area of forest which can be managed efficiently and sustainably based on its basic function and purpose. Presence of FMUs expected providing optimal role for realizing forest 
sustainability and people prosperity, and minimizing conflicts in forestry sector. Tasks and functions of FMU are doing to forest management, which were previously under an authority of Government and Regional Forestry Service. Length of FMU development (1999-present) indicates a bottleneck in its internalization process. This bottleneck is due to no understanding of the importance of FMU development and concept. It has caused resistance in its formation process.

Innovation can take form an idea, practice, and object (Rogers 2003), knowledge (Signorini 2001; Rogers 2003; Cowan \& Jonard 2004; Lambiotte \& Panzarasa 2009; Kimura 2011), technology (Signorini 2001; Spilsbury \& Nasi 2004; Kimura 2011), information (Lambiotte \& Panzarasa 2009), perception, and mindframe. According to Rogers (2003), there are 5 steps in the innovation decision process by individuals (decision-making unit) i.e. knowledge stage, persuasion stage, decision stage, implementation stage and confirmation stage. The decision-making process of innovations can be understood through its diffusion process, so it can be known progress level of its adoption. Diffusion is a dispersion, dissemination, or propagation (Bintarto \& Hadisumarmo 1987); the process in which an innovation is communicated through certain channels over time among the members of a social system (Rogers 2003). Two types of diffusion are (1) expansion diffusion, consists of contagious diffusion and cascade diffusion (i.e. diffusion of innovations and hierarchic diffusion), and (2) relocation diffusion (Bintarto \& Hadisumarmo 1987). Understanding of the concept of diffusion of innovation (knowledge) has been implication to development of the concept utilization in a variety of research policy, which describes influence of the knowledge diffusion and the stakeholders interactions in the policy process (Deelstra et al. 2003; Spilsbury \& Nasi 2004; Scott et al. 2008; Hermans \& Thissen 2009; Reed et al. 2009; Klenk \& Hickey 2011; Weiss et al. 2011).

Based on the reason, questions of this research were how knowledge of FMU development policy transfered over a network and what kind of its interaction patterns. This indicates a communication process over network. The study objective was analyzing process of knowledge diffusion of FMUs development policy and stakeholders interaction in both PFMU. The knowledge diffusion process illustrates how the knowledge diffusion pattern of stakeholders and their interaction within responds to the policy internalized. It also illustrates the communication network dffusion were built and the actors role in network. Indicative strategy is needed as anticipating and overcoming an obstacle in its internalization process.

\section{Methods}

The study approach was using the qualitative descriptive method. Research locations purposively selected i.e. PFMU Batutegi-Lampung Province and PFMU Kotaagung UtaraTanggamus Regency, Lampung Province. Data collected by conducting in-depth interviews, direct observation, and document study. Knowledge in the study is first time of respondent to hear the FMUs concept, so the knowledge diffusion doesn't reflect an overall content. Stakeholders perception based on the social interaction analysis in which knowledge producted. This perception is the strategic issues that arise from the stakeholders interaction. Interviews conducted using snowball technique. The first respondent as a key informants were PFMU Batutegi and PFMU Kotaagung Utara. Stakeholders in this study were 17 respondents from PFMU Batutegi and 11 respondents from PFMU Kotaagung Utara.

Data analysis Knowledge diffusion describes knowledge progress on FMUs concept in both PFMU and stakeholders interaction involved, which analyzed using:

1 Interaction analysis were done using IDS and network analysis. Network analysis used socio-spatial analysis, which was a logical diffusion technique that considering space element and time (Bintarto \& Hadisumarmo 1987; Julijanti 2005; Lulka 2008). This analysis illustrates the pattern of communication networks which was built among stakeholders. Latour (1996) stated that diffusion process could also be analyzed based on domestication as the central point in human non-human relations (Lulka 2008). Lulka (2008) used to geographical site and its motion space, and Pregernig (2000) stated that route was not organized or planned formerly. Network analysis was used to analyze the pattern of actors relationships that have a role and influential in the decision-making process through the knowledge diffusion of FMU policy. Three framework-approaches (discourse/narrative, actors/networks and politics/interest) in IDS analysis (2006) was used to knowing stakeholders-interaction in response to knowledge on FMUs concept, actors position in network, and power dynamics that accelerating or inhibiting it. An understanding of stakeholders behavior in policy process could also be analyzed through 4 dimensions, i.e. network, perceptions, values and resources (Hermans \& Thissen 2009); relationships of influence, power/authority, and interests (Reed et al. 2009).

2 Descriptive analysis carried out to explain both analysis and its relationship patterns and indicative strategies to anticipate and overcome. Indicative strategy builds upon the stakeholders interaction analysis. Study of Salazar and Alper (1996) stated that the perception of political actors affects their strategy and behaviors in a political context.

\section{Results and Discussion}

Knowledge diffusion of FMUs concept and its interaction pattern Knowledge occurs when an individual (decisionmaking unit) is exposed to an innovation's existence and gains an understanding of how it functions (Rogers 2003). The knowledge diffusion is an early stage in the decisionmaking processes of the FMU development policy. Knowledge diffusion could be in form of the exchange of information (Rogers 2003; Cowan \& Jonard 2004), technology (Spilbury \& Nasi 2004), perceptions, and knowledge transaction (Pregernig 2000) among stakeholders involved. Information, knowledge, perception exchanged, transferred, or transactioned over network. Rogers (2003) has identified seven characteristics of individuals (decisionmaking unit) influencing decision of innovation, i.e. 
education, social status, exposure to mass media channels of communication, exposure to interpersonal channels, more contact with change agents, social participation, and cosmopolite.

PFMU Batutegi Formation history of PFMU Batutegi could be known through knowledge diffusion of FMUs concept in its decision-making process. This knowledge diffusion illustrates the stakeholders interaction patterns involve. There are 3 types of knowledge related to innovations, i.e. kind of innovation, how does it work, and why does it work (Rogers 2003). Knowledge diffusion of FMUs concept in PFMU Batutegi had been occurred in 2004-2012 (Figure 1).

According to Rogers (2003), knowledge received highly depends on previous conditions, such as previous practice, felt needs/problems, innovativeness, and norms of social system. Since the publication of Law Number 41/1999 until 2003, FMUs concept which understood is the old version. Forest management context still dominated by concession concept, so there was perception that "FMU was similar to concession." In 2004, a new understanding on it began known by forestry services, professional and Watala. Forestry Services and professional provided an understanding of it to other stakeholders intensively, which implicates to change of mindset that FMU must constructed as an organization on site level. Understanding of forestry services and professional are inseparable from role of Directorate General of Forestry Planning in internalization process of FMU development policy. Understanding of FMUs policy in Ministry of Forestry could penetrate to Government of Lampung Province through an internalization process. It packaged in socialization, discussion/public consultation, and meetings, both formally and informally. Internalization was continued to other stakeholders, especially candidates of FMU head on the urgency of FMU in Lampung Province. It has encouraged the other stakeholders to learn and understand of FMU.

Figure 1 shows that knowledge diffusion influenced by network and it didn't influence by administrative boundaries. Study of Cowan and Jonard (2004), among others, have shown that the extent of diffusion affected by network

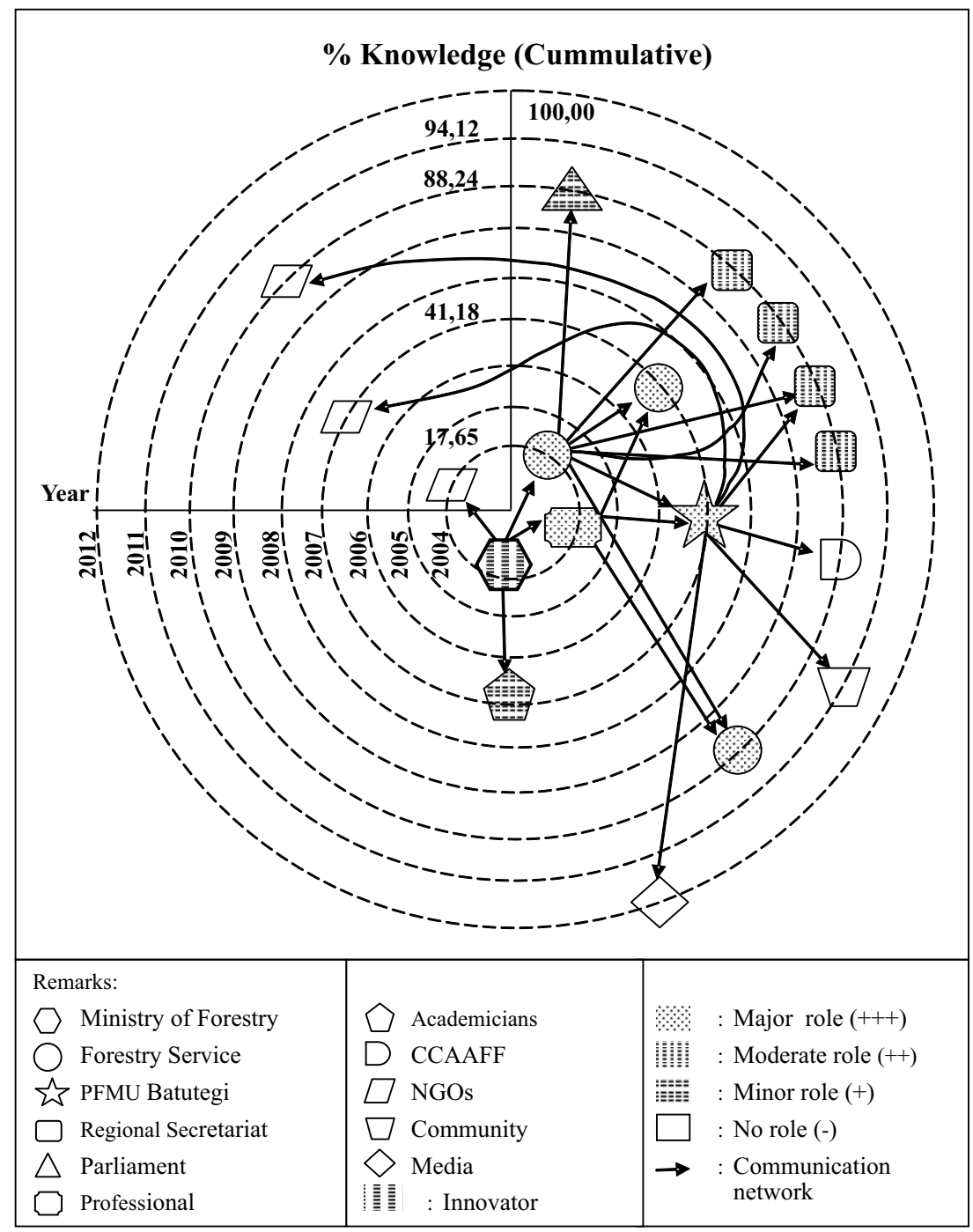

Figure 1 Knowledge diffusion patterns of FMUs concept in PFMU Batutegi in 2004-2012. 
structure in which the diffusion takes place. Stakeholders built a network so FMUs concept could known and understood by others. Intensivity of a network can encourage acceleration the FMU policy adoption processes.

Network was built to capture the change agents in region in the dissemination process of FMUs concepts. A change agent is an individual who influences clients' innovationdecisions in a direction deemed desirable by change agency (Rogers 2003). Study of Jakobsen and Aarset (2010) states that regulations can restrict innovations and facilitate the innovations processes. Professionals as a change agent were very instrumental in knowledge diffusion processes. In-dept understanding on FMUs concept has acquired in 2007, when the Government Regulation Number 6/2007 published. It became strong base to provide an understanding to other stakeholders especially in the Forestry Services. Changes in understand of it which leads to adoption of FMUs policy in 2010.

Institutional processes was obtained through dominant discourse which as if are outcome of a democratic dialogue that is free from power relations, these processes could be encourage actors to actively adopt the dominant discourse (Archel et al. 2011). The issuance of Government Regulation Number 6/2007 has triggered adoption of FMU policy. In 2007, stakeholders who knows FMUs concept, i.e. PFMU Batutegi, academicians, Kawantani, and the Regional Technical Implementation Unit (RTIU)-Inventory and Forest Mapping. The expansion of knowledge diffusion did not occur in 2008 until 2009. Incessant of internalization process of FMU policy by Directorate General of Forest Planning has been welcomed by Government of Lampung Province. In 2010, FMUs concept had been familiar with 8 stakeholders, i.e. regional secretariat, parliament, field of inventory and forest management, counseling coordination agencies of agricultural, fisheries and forestry (CCAAFF), and WWF. Organization Bureau and Provincial Parliament held a special meeting to discuss FMU organization. All stakeholders who have an authority as decisions makers have agreed and consented to adoption of FMU. They were Regional Secretariat, Parliament, and Forestry Service. PFMU Batutegi stipulated based on the Ministry of Forestry Decree Number SK. 68/Menhut-II/2010.

When an innovation will be disseminated to target, it is necessary to known characteristics of target or adopters, which is according to Rogers (2003) are socio-economic characteristics, personality variables, and communication behavior. Community knows FMU policy in 2011. Public's understanding of FMUs concept and urgency of FMU existence is necessary "implanted". PFMU Batutegi must be able to communicate FMUs policy to community, both through a socialization and meeting with communityThis process indirectly accepted by community who has already existed there. Community started occupying Batutegi region in 1970, and then in 1980, and the last coming in 1999. Diffusion of knowledge on FMUs concept culminated in $2012(100 \%)$. Media was the last stakeholders who knew about it.

PFMU Kotaagung Utara The development policy adoption of PFMU Kotaagung Utara can be seen from knowledge diffusion progress, which is showed its network diffusion. Knowledge diffusion of development policies of PFMU Kotaagung Utara in decision-making processes did not separate from its formation history (Julijanti et al. 2013). It occurred in 2004-2012 (Figure 2).

In 2004, it has not occurred in Tanggamus Regency. That time, FMUs development policy was began known by professional. Formerly, professional was working as the Field Head of Security and Protection Forest of Forestry Service of Lampung Province. Professional knowledge is further strengthening in line with internalizing process of FMUs idea in Ministry of Forestry (Julijanti et al. 2013). This internalization process intensively carried out after Government Regulation Number 6/2007 published. It has implications on the knowledge dissemination process of FMUs concept in Tanggamus Regency. Although in 2004, it has been known in Lampung Province, but not familiar in Tanggamus Regency.

In 2007, FMUs concept has known by academicians and the Field of Security and Forest Protection of Forestry Service and Plantation. Knowledge of FMUs concept was known only by foresters (who are forestry background) and no spread to non-forestry stakeholders (who are non-forestry background). The condition might inhibit the policy communication process of FMU development. Stakeholders communication was not optimal, so knowledge diffusion tends to be linier (Julijanti et al. 2013).

In 2009, it has been familiar for non-forestry stakeholders, namely the Head of Business and Institutional of Forestry Service and Plantation. Most of FMUs development stages were facilitated by Directorate General of Forestry Planning as a precondition of FMU formation, which covered design, reserve direction, formation, and stipulation. Basic of FMU formation in Lampung Province was letter of Lampung Governor Number 522/4577/ III.16/2009 dated December 14, 2009 on proposed establishment of 16 unit of FMU in Lampung Province. In 2010, FMUs concept has been known by Regional Secretariat, Forestry Service and Plantation, and WWF. In 2011, parliament and community started known it. It has implications to enhancement of understanding on importance of FMU. PFMU Kotaagung Utara was doing socializing to decision makers and community both formally and informally (Julijanti et al. 2013).

In 2012, all stakeholders have been familiar with FMUs concept. Counselor in the Counseling Activities Office of Agricultural, Fisheries and Forestry (CAOAFF) and media are the last stakeholders who known it. CAOAFF is an institution for counselor workers of forestry, which is formerly staff in Forestry Service and Plantation of Tanggamus Regency. Coordination of counseling activity with CAOAFF was starting in 2012. In September 2012, both media in Lampung Province and Tanggamus Regency have named "PFMU Kotaaagung Utara" as the title and main topics (Julijanti et al. 2013). Before 2012, media never called "name of FMUs" eventhough there was any news related to Protection Forest of Tanggamus Regency. It shows that interest of media on presence of PFMU Kotaagung Utara was still low, and agenda setting of media tends to other issues than PFMU (Julijanti et al. 2013). 


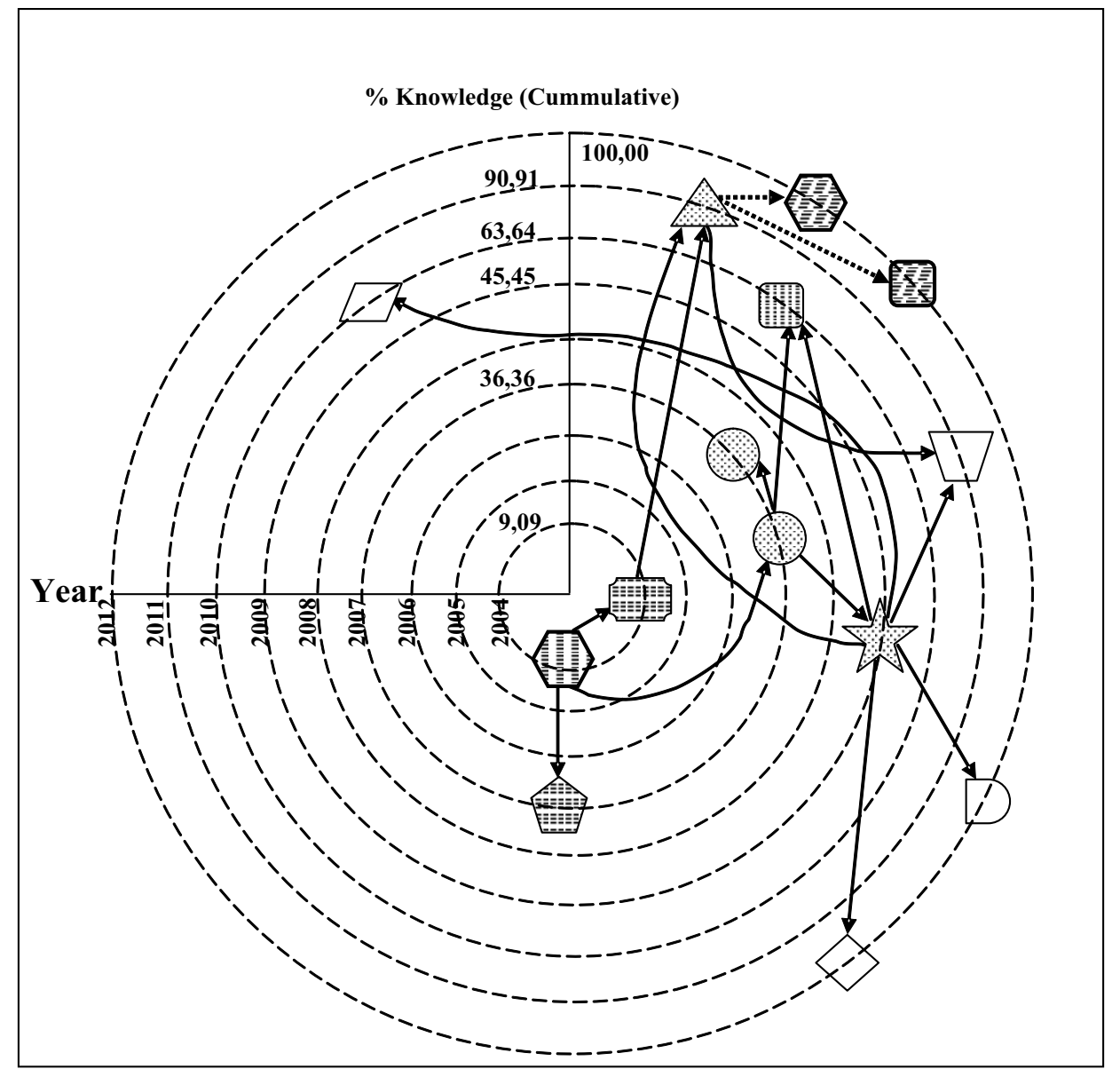

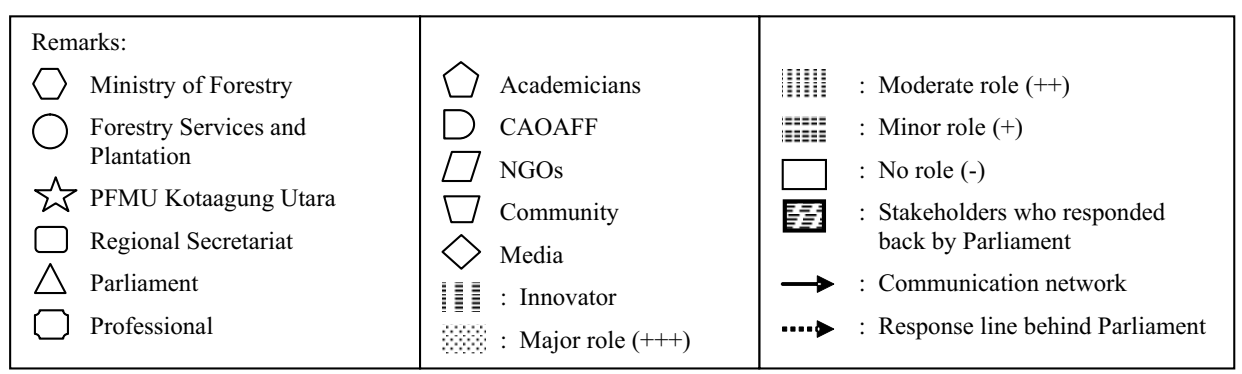

Figure 2 Knowledge diffusion pattern of FMUs concept in PFMU Kotaagung Utara in 2004-2012.

Knowledge diffusion of FMUs concept in Tanggamus Regency was not affected by administrative boundaries (distance factor), but it was influenced by networking (Julijanti et al. 2013). It describes diffusion of stakeholders perception in decision-making process of development policies of PFMU Kotaagung Utara. Interpersonal communication among foresters have been triggered the knowledge diffusion process from Ministry of Forestry towards professionals in Lampung Province. Communication over an interpersonal network occurs when they will decide to adopt or not adopt an innovation, which depends on communicated experience (Rogers 2003).

Response of stakeholders on a policy is influenced by his knowledge on policy (Julijanti et al. 2013). Rate of innovation adoption in a social system is influenced by the involvement of opinion leaders, namely individuals who lead in influencing the opinions of others (Rogers 2003). Until 2012, adoption of FMU policy in Tanggamus Regency has reached $100 \%$. The role of PFMU Kotaagung Utara and parliament is dominant in accelerating of its decision-making process. Their enthusiasm and respon on FMUs policy have been encouraged acceleration the formation process of PFMU Kotaagung Utara. PFMU Kotaagung Utara was built based on agreement from Head of Tanggamus Regency and parliament, even nowadays it becomes Working Unit of Regional Devices (WURD).

How does stakeholders worked? Based on analysis, acceleration of knowledge propagation that occurs in both PFMU has influenced by network rather than administrative 
boundaries (distance among stakeholders). Knowledge diffusion of FMUs concept in both PFMU tends to the cascade diffusion. This diffusion pattern shows that the structure of communication network that is built to put the Ministry of Forestry as an innovator in the internalization process of FMU policy. The first change agent as center of the FMU policy diffusion (center/core) in both PFMU are Forestry Service/Forestry and Plantation Service and professional. The second change agent are PFMU and parliament (Tanggamus Regency). Periphery position in both PFMU occupied by parliament (Lampung Province), Regional Secretariat, academics, BP3K/BP4K, NGOs (Watala and WWF), public, and media. Ministry of Forestry builds a network both formally (discussions and other technical meetings) and informally (forester network). Understanding the nature of networks is very important in order to more understand the diffusion process (Rogers 2003). Knowledge diffusion in new FMUs concepts in PFMU Batutegi has occurred since 2004, while in PFMU Kotaagung Utara in 2007 (Table 1).

If it was viewed from their developmental duration, PFMU Kotagung Utara was still faster than PFMU Batutegi. This shows that there is another trigger that accelerating its knowledge diffusion process, i.e. role of opinion leaders (PFMUs and Parliament). Opinion leaders are change agents who help diffusion of knowledge through its leadership trait (Feder \& Savastano 2006). Leadership skills in both PFMU said to comparable both terms of capability and network. Leadership skills without strong support of other stakeholders (Parliament) could be a barrier in spread of innovations. Strong support from Forestry Service is quite necessary in both PFMU.

Parliament as regional legislative could affect regional executive in decision-making processes, and vice versa. In generally, regional policy was published through Parliament approval. Crow (2008) was found that the stakeholders collaboration effectively influencing legislative in the policy changes. Parliament could be slow the diffusion process when knowledge of FMUs concept has not enough, similarly to local government. It could be cause a misunderstanding on FMUs concept. During the FMU development process in Lampung Province, Provincial Forestry Service has sought to enhance understanding of it, which has not been touched by Provincial Parliament. Activity cost of FMU had been accommodated in budget, however it was understood by Parliament that Forest Service needed additional budget for PFMU Batutegi. This condition was opposite with PFMU Kotaagung Utara. Parliament of Tanggamus Regency was very aggressive in supporting of FMU development. Parliament was very enthusiastic if there are problems in forest area (registers), however which is known a register not FMU. Media was more familiar with registers than FMU.

FMU development is not understood as a regional incentive to get revenue from forestry sector. Local Government considers that construction of FMU is costly because of build a new organization. Another assumption that tasks and functions of FMU could be still performed by related Forestry Service, so FMU did not need. Subsequent misunderstandings arised when most of facilities and infrastructure of FMU development were facilitated by Ministry of Forestry. It has understood by local government that FMU development was still undeniably centralized. FMUs concept did not understand by other stakeholders, so it implied the understanding and different perspective on it. Misunderstanding will not happened if there is a common understanding (collective agreement) on it. Collective agreements was constructed through stakeholders interaction based on their knowledge, discourse, power of actors and networks, and an actors interests (Kartodihardjo 2008).

Academicians in Lampung Province had a sufficient role in internalization process of FMU policy related to discussion on FMU design, forest governance, workshops, socialization, and making plans of long-term management of FMU. Academicians involvement have mostly based on invitation of Government, Forest Service and Technical Implementation Unit of Central Government. Professional role in diffusion process is also important, but this role is not optimal without support from other stakeholders as mouthpiece. Study of Borzel (1998) indicates that involvement of non-governmental organizations (public and private actors) in government employment was needed (Dawkins \& Colebatch 2006).

Duration of policy adoption process of FMU in Lampung Province was 8 years in both PFMU Batutegi and 8 years in PFMU Kotaagung Utara. It indicated that professionals were unoptimal in undertaking its role as change agents. Change agents can accelerate the process of innovation adoption,

Table 1 Rate of diffusion of knowledge in PFMU Batulegi and PFMU Kotaagung Utara

\begin{tabular}{|c|c|c|c|c|c|}
\hline \multirow[b]{2}{*}{ Year } & \multicolumn{2}{|c|}{ PFMU Batutegi } & \multicolumn{3}{|c|}{ PFMU Kotaagung Utara } \\
\hline & Knowledge (\%) & Rate of diffusion & Knowledge (\%) & Rate of diffusion & Ratio for speed \\
\hline 1 & 2 & $3=(b-a) / b$ & 4 & $5=(d-c) / d$ & $6=5 \times 1.55$ \\
\hline 2004 & $17.65^{\mathrm{a}}$ & - & $9.09^{\mathrm{c}}$ & - & - \\
\hline 2007 & $41.18^{\mathrm{b}}$ & 0.57 & $36.36^{\mathrm{d}}$ & 0.75 & 1.16 \\
\hline 2009 & 41.18 & - & 45.45 & 0.20 & 0.31 \\
\hline 2010 & 88.24 & 0.53 & 63.64 & 0.29 & 0.45 \\
\hline 2011 & 94.12 & 0.06 & 81.82 & 0.22 & 0.34 \\
\hline 2012 & 100.00 & 0.06 & 100.00 & 0.18 & 0.28 \\
\hline Informant & 17 & & 11 & & \\
\hline Ratio & 1 & & 1.55 & & \\
\hline Average & & 0.16 & & & 0.32 \\
\hline
\end{tabular}


slow down the diffusion process and prevent the innovation adoption (Rogers 2003). Positional mutation as consequence of regional political changes became a barrier factor of professionals movement. When professionals got promotion, in general, knowledge of FMUs concept also carried, so there was no progress in diffusion process (2004-2007). It could understood that direction of political movement was influenced on changes of bureaucratic organizational structure. It had implication on the personnel positional mutation of related working unit. Knowledge transfer process about FMUs concept among regional stakeholders did not optimum, thus it potentially emerged misunderstanding on it. It can slow down the diffusion process.

Indicative strategy Changes in stakeholders perception on FMUs concept can be understood as a reconstruction process. This process begins with internalization process of new FMUs concept. Veenman et al. (2009) has been understood that de-institutionalization process refers to institutionalization process which related to 4-dimensional approach of policy arrangements: discourse, power, rules and actors. Collier and Scott (2009) were using the actors narrative to identify conflicts of rationality, knowledge and values in nature-human relationships as a basis for decision- making process. Kartodihardjo (2006b) says that obstacle of the policy renewal orientation sourced from policy narratives and discourses that embedded in the beliefs of decision makers. FMU development policies tends preventive so slower adopted because usually arise resistance. It is unlike incremental policy. It more rapidly adopted because it directly overcomes on a problem that appears, however it did not touch its root problems.

Based on an analysis, it was known that the stakeholders interaction in diffusion process can speed up, slow down, and prevent the FMU policy adoption in both PFMU. This process influenced by role of change agents. When change agents seriously and continuously securing the FMU policy adoption, then adoption process can running faster, and vice versa. Resistance and obstacles on it, which can be overcomed if there are communication strategies based on knowledge of FMUs concept. Policy change is influenced by diffusion process of knowledge based on theories that are relevant to policy and empirical experiences (learning process) that takes place iteratively, and it will affect stakeholders behavior in interacting as responding to certain situations (Naf \& Bisang 2001). Communication strategy is an indicative strategy to accelerating of understanding the FMUs concept (Table 2).

Table 2 Indicative stategy of FMU development based on knowledge

\begin{tabular}{|c|c|c|c|c|}
\hline Perception/strategic issues & Narrative & Actor/network & Politics/interest & Indicative strategy \\
\hline $\begin{array}{l}1 \text { Register is more familiar } \\
\text { than FMU } \\
2 \text { FMU is not understood } \\
\text { yet as an incentive of } \\
\text { local revenue } \\
3 \text { FMU development is a } \\
\text { cost center } \\
4 \text { FMU development was } \\
\text { still centralized } \\
5 \text { FMU is regional office } \\
\text { of central government } \\
6 \text { FMU provides an } \\
\text { opportunity to get a } \\
\text { special allocation fund } \\
\text { from central government } \\
7 \text { FMU can as a solution } \\
\text { of water availability } \\
8 \text { FMU can minimizing } \\
\text { forest damage }\end{array}$ & $\begin{array}{l}\text { Disagreements } \\
\text { among stakeholders } \\
\text { because stakeholders } \\
\text { did not have } \\
\text { sufficient } \\
\text { understanding of } \\
\text { FMUs concept }\end{array}$ & $\begin{array}{l}\text { PFMU Kotaagung } \\
\text { Utara } \\
1 \text { Core/center: } \\
\text { - The first change } \\
\text { agent (Forestry } \\
\text { and Plantation } \\
\text { Service, } \\
\text { professional) } \\
\text { - The second } \\
\text { change agent } \\
\text { (PFMU, } \\
\text { parliament) } \\
2 \text { Periphery (Regional } \\
\text { Secretariat, } \\
\text { academics, NGOs, } \\
\text { CAOAFF, media, } \\
\text { community) }\end{array}$ & $\begin{array}{l}1 \text { Changing of bureaucratic } \\
\text { organizational structure } \\
\text { and changing of } \\
\text { bureaucratic } \\
\text { organizational structure } \\
\text { and the quickly job } \\
\text { mutation have } \\
\text { implications an interest in } \\
\text { shift by change agent } \\
2 \text { Good coordination } \\
\text { between executive and } \\
\text { legislative have } \\
\text { implications on } \\
\text { fulfillment of mutual } \\
\text { interest (adoption of } \\
\text { FMU) } \\
3 \text { Similarity of political } \\
\text { ideology in organization } \\
\text { has implications to } \\
\text { acceleration the } \\
\text { internalization process of } \\
\text { FMU policy }\end{array}$ & $\begin{array}{l}1 \text { Intensive approach to legislative for } \\
\text { influences regional executives } \\
\text { related to better understanding on } \\
\text { FMUs concept } \\
2 \text { Equate perceptions by building a } \\
\text { networks and giving opportunity an } \\
\text { active involvement of all } \\
\text { stakeholders in order to feel } \\
\text { concerned with FMU development } \\
\text { (eg, to plan a joint activities) } \\
3 \text { Building an opinion about the } \\
\text { importance of FMU by cooperation } \\
\text { with media, NGOs, } \\
\text { CCAAFF/CAOAFF, academics } \\
\text { (counseling, media news, exhibition) } \\
4 \text { Maintaining networks among } \\
\text { stakeholders (legislative, executive, } \\
\text { professional, NGOs) in order to } \\
\text { supporting the PFMU through the } \\
\text { formal discussion forums (eg. } \\
\text { workshops) and informal (personal } \\
\text { visit) } \\
5 \text { Building an active communication } \\
\text { (central and regional) both formal } \\
\text { (public discussions/workshops, } \\
\text { technical meetings, etc.) and } \\
\text { informal (personal discussion, } \\
\text { telephone, etc.) to overcoming } \\
\text { bureaucratic obstacles } \\
6 \text { Optimizing the role of National } \\
\text { Secretariat of FMU to accelerate } \\
\text { understanding of the FMUs concept } \\
\text { (direct visits to parliament and } \\
\text { provincial/district government) }\end{array}$ \\
\hline
\end{tabular}

- Data analysis based on interviews and document studies was using IDS analysis.

- The role of actor/network obtained from the knowledge diffusion analysis 


\section{Conclusion}

The knowledge diffusion of FMUs concept in both PFMU tends to cascade diffusion. This was shown by internalization process of FMU policy is top down (CentralForestry Service-PFMU). The results showed that knowledge diffusion in the internalization process of FMU development policies influenced by network, the role of change agents i.e. opinion leaders (PFMU, Parliament and Forestry Service) and professional, and willingness to know and understand of FMUs concept. Optimalization of role conducted through intensive approach especially to a change agent who has the same interest to programs of the Ministry of Forestry.

\section{Recomendation}

Similarity of political ideologies have implications to acceleration of internalization process of the FMU development policy (PFMU Kotaagung Utara). This indicates that there is political process in the internalization process. Therefore, changes in orientation of policy communication required i.e. from conventional communication (forestry organizations) becomes to crossinstitutional communication (parliament).

\section{Acknowledgements}

Thanks to Ministry of Forestry for supporting $\mathrm{PhD}$ Program in Bogor Agricultural University, Forestry Research and Development Agency for opportunity to participation in the second International Conference of Indonesian Forestry Researchers (INAFOR), 27-28 August 2013 in early version, and Bogor Agricultural University for financial assistance in the 2nd INAFOR 2013.

\section{References}

Archel P, Husillos J, Spence C. 2011. The institutionalization of unaccountability: Loading the dice of corporate social responsibility discourse. Accounting, Organizations and Society 36:327-343. http://dx.doi.org/10.1016/ j.aos.2011.06.003.

Bintarto R, Hadisumarmo S. 1987. Metode Analisa Geografi. Jakarta: LP3ES.

Collier MJ, Scott M. 2009. Conflicting rationalities, knowledge and values in scarred landscapes. Journal of Rural Studies 25:267-277. http://dx.doi.org/10.1016/ j.jrurstud.2008.12.002.

Cowan R, Jonard N. 2004. Network structure and the diffusion of knowledge. Journal of Economic Dynamic \& Control 28:1557-1575. http://dx.doi.org/10.1016/ j.jedc.2003.04.002.

Crow DA. 2008. Stakeholder behavior and legislative influence: A case study of recreational water rights in Colorado. The Social Science Journal 45:646-658. http://dx.doi.org/10.1016/j.soscij.2008.09.008.

Dawkins J, Colebatch HK. 2006. Governing through institutionalised networks: The governance of Sydney
Harbour. Land Use Policy 23:333-343. http://dx.doi.org/ 10.1016/j.landusepol.2004.09.006.

Deelstra Y, Nooteboom SG, Kohlmann HR, Berg J, Innanen S. 2003. Using knowledge for decision-making purposes in the context of large projects in The Netherlands. Environmental Impact Assessment Review 23:517-541. http://dx.doi.org/10.1016/S0195-9255(03)00070-2.

Feder G, Savastano S. 2006. The role of opinion leaders in the diffusion of new knowledge: The case of integrated pest management. World Development 34(7):1287-1300. http://dx.doi.org/10.1016/j.worlddev.2005. 12.004 .

Hermans LM, Thissen WAH. 2009. Actor analysis methods and their use for public policy analyst. European Journal of Operational Research 196:808-818. http://dx.doi.org/ 10.1016/j.ejor.2008.03.040.

[IDS]. 2006. Understanding Policy Processes: A Review of IDS Research on Environment. United Kingdom: Institute of Development Studies, University of Sussex.

Jakobsen SE, Aarset B. 2010. Institutions as facilities for change? A study of the coherence between political regulations and innovations within the pelagic fisheries sector in Norway. Marine Policy 34:928-934. http://dx.doi.org/10.1016/j.marpol.2010.01.018.

Julijanti. 2005. Perubahan pemanfaatan lahan di kawasan dataran tinggi Dieng: studi kasus difusi spasial usaha tani kentang (UTK) di Desa Batur dan Desa Dieng Kulon Kecamatan Batur Kabupaten Banjarnegara [thesis]. Yogyakarta: Universitas Gadjah Mada.

Julijanti, Nugroho B, Kartodihardjo H, Nurochmat DR. 2013. Diffusion of knowledge: The patterns of policy adoption of Protection Forest Management Unit of Kotaagung Utara in Tanggamus Regency Lampung Province. Paper. The Second International Conference of Indonesian Forestry Researchers (INAFOR), 27-28 August 2013. Forestry Research and Development Agency, Ministry of Forestry.

Kartodihardjo H. 2006a. Problem of institutional capacity and direction of forestry policy: Three case study. Jurnal Manajemen Hutan Tropika 12(3):14-25.

Kartodihardjo H. 2006b. Masalah kelembagaan dan arah kebijakan rehabilitasi hutan dan lahan. Jurnal Analisis Kebijakan Kehutanan 3(1):29-41.

Kartodihardjo H. 2008b. Discourses arid actors in the forest policy formulation: Problems of rational framework. Jurnal Manajemen Hutan Tropika 14(1):19-27.

Kartodihardjo H. 2010. Soal tenurial, KPH dan "the trapped administrators". Warta Tenure 8:5-6.

Kimura Y. 2011. Knowledge diffusion and modernization of rural industrial clusters: a paper manufacturing village in Nothern Vietnam. World Development 39(12):2105- 
2118. http://dx.doi.org/10.1016/j.worlddev.2011.04.017.

Klenk NL, Hickey GM. 2011. Government science in forestry: characteristics and policy utilization. Forest Policy and Economics 13:37-45. http://dx.doi.org/10. 1016/j.forpol.2010.08.005.

Lambiotte R, Panzarasa P. 2009. Communities, knowledge creation, and information diffusion. Journal of Informetric 3:180-190. http://dx.doi.org/10.1016/ j.joi.2009.03.007.

Lulka D. 2008. Non-linear diffusion: bison on the hoof and on the rail in the United States. Geoforum 39:1007-1020. http://dx.doi.org/10.1016/j.geoforum.2007.10.019.

Naf IK, Bisang K. 2001. Rethinking recent changes regimes in Europe through property-rights theory and policy analysis. Forests Policy and Economic Journal 3:99-111.

Pregernig M. 2000. Putting science into practice: the diffusion of scientific knowledge exemplified by the Austrian 'Research Initiative Against Forest Decline.' Forest Policy and Economics 1:165-176.

Reed MS et al. 2009. Who's in and why? a typology of stakeholder analysis methods for natural resource management. Journal of Environmental Management 90:1933-1949. http://dx.doi.org/10.1016/j.jenvman. 2009.01.001.

Rogers EM. 2003. Diffusion of Innovations. Fifth Edition. United State: Free Press.
Salazar DJ, Alper DK. 1996. Perceptions of power and the management of environmental conflict: forest politics in British Columbia. The Social Science Journal 33(4):381-399.

Scott N, Cooper C, Baggio R. 2008. Destination network: four Australian cases. Annals of Tourism Research 35(1):169-188. http://dx.doi.org/10.1016/j.annals. 2007.07.004.

Signorini I. 2001. Literacy and Communicative (in)flexibility: interactional failure in Brazilian programs of diffusion of knowledge. Journal of Pragmatics 33:969-997.

Spilsbury MJ, Nasi R. 2004. The interface of policy research and the policy development process: challenges posed to the forestry community. Forest Policy and Economics 8:193-205. http://dx.doi.org/10.1016/j.forpol.2004.09. 001 .

Veenman S, Liefferink D, Arts B. 2009. A short history of Dutch forest policy: the 'de-institutionalization' of a policy arrangement. Forest Policy and Economics 11:202-208. http://dx.doi.org/10.1016/j.forpol.2009. 03.001 .

Weiss K, Hamann M, Kinney M, Marsh H. 2011. Knowledge exchange and policy influence in a marine resource governance network. Global Environmental Change 22:178-188. http://dx.doi.org/10.1016/j.gloenvcha. 2011.09.007. 